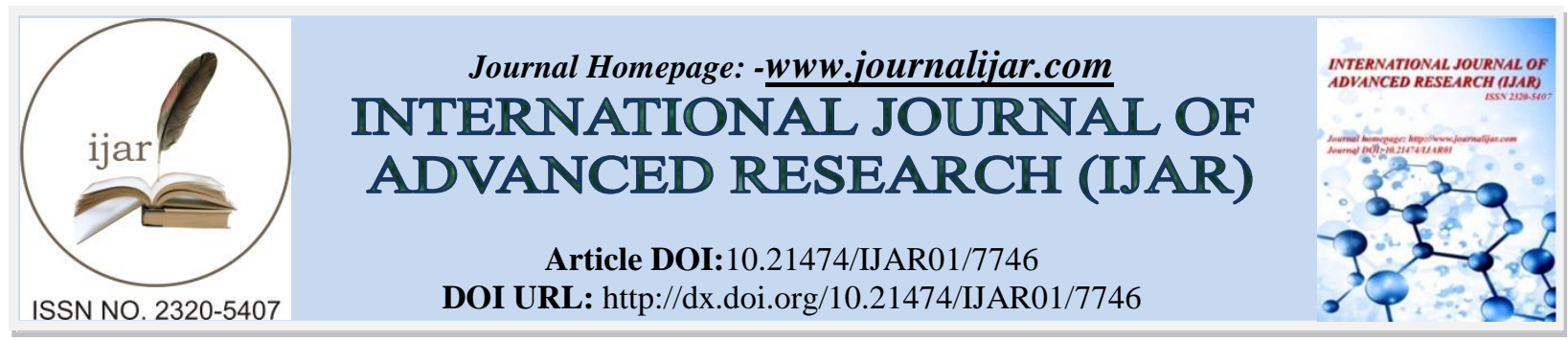

RESEARCH ARTICLE

\title{
POLLEN MORPHOLOGICAL STUDIES IN FIVE SPECIES OF LEEA D. ROYEN EX L. FROM KERALA.
}

Raji R Nair ${ }^{1}$, Devipriya $V^{2}$, Smitha $S$ Nair ${ }^{1}$ and Regy Yohannan ${ }^{1}$.

1. Post Graduate \& Research Department of Botany, SreeNarayana College, Kollam, Kerala.

2. Principal, SreeNarayana Guru College, Chelannur, Kozhikode, Kerala, South India.

\section{Manuscript Info}

Manuscript History

Received: 23 July 2018

Final Accepted: 29 August 2018

Published: September 2018

Keywords:-

Leeaceae, Vitaceae, Kerala, pollen morphology, exinearchitecture.

\section{Abstract}

The pollen morphology of ten accessions representing five species of Leea D. Royen ex L.collected from different parts of Kerala State, South India, were studied. The major palynological features appear to be highly conserved with the pollen grains being consistently 3colporate, prolate-spheroidal to subprolate and medium-sized with microreticulate exine ornamentation. SEM analysis revealed large broad colpi with slightly winged margins, tall muri with warted upper surfaces and irregularly heterobrochate narrow lumina. The luminal floors were not clearly visible due to luminal depth and heavy wax deposition, more frequently at the mesocolpium. The lumina tend to elongate and narrow at the mesocolpium assuming a rugulate nature. Earlier reports of similar pollen traits from the close kin Vitaceae reflect the palynological affinity between the two groups, justifying the recent inclusion of the genus as a subfamily under the Vitaceae.

Copy Right, IJAR, 2018,. All rights reserved.

\section{Introduction:-}

Leea D. Royen ex L., the monophyletic member of the tropical family Leeaceae, comprises 70 species world over, and has 34 species reported from Asia and Africa, of which six species have so far been recorded from Kerala (Sasidharan, 2004). The members are mostly shrubs, trees or herbs with simple or pinnate leaves, many flowered corymbose cymes, reflexed petals, variously lobed stamina tubes, basal ovules in 2-4 carpellary pistils and indehiscent berries (Risdale, 1974, 1975). The genus was originally considered under the economically important grape family, the Vitaceae, from which it was later separated out as a distinct family - the Leeaceae owing to the absence of tendrils, shrubby habit, presence of floral disc, presence of staminoidal tube, variations in ovule and carpel number etc. (Molina, 2009). However, the genus is presently being considered as a subfamily (Leeoideae) under the Vitaceae (APG I 1998 to APG IV, 2016).

Phylogenetic studies and taxonomic categorizations have at present assumed a multidimensional aura, demanding the collection of data from variant sources for systematic elucidations. Pollen microstructural analysis employing Scanning Electron microscopy unveils the pollen surface architecture yielding a vast array of details pertaining to the exine ornamentation and aperture, which along with other traits such as exine strata, pollen size, pollen shape etc. have become very valuable as 'palynological markers' at all taxonomic hierarchies. A perusal of the literature on the pollen of the genus Leea yielded scanty results, as such studies have focused largely on the palynology of the larger group, the Vitaceae (Erdtman, 1952; Tarnavschi and Petria, 1968; Moore et al. 1991; Inceoglu et al. 2000; 
Punt et al. 2003; Perveen and Qaiser, 2008; Najmaddin et al. 2011, Najmaddin, 2014). Consequently, Leea pollen have received meagre attention, and the aim of the present study is to gather data on the pollen morphology of the genus. The study includes detailed comparative interspecific analysis of the pollen from five species of Leea from different parts of Kerala, South India, using LM and SEM studies.

\section{Materials and Methods:-}

The details regarding the five species of Leea collected from various locations in the State of Kerala for the present study are furnished in Table 1. Fresh polliniferous materials from the collected specimen were fixed directly in glacial acetic acid. Pollen preparations were made by the acetolysis method standardized by Erdtman (1952) and modified by Nair (1970).

Table 1:- List of five species of Leea collected from different parts of Kerala with locality

\begin{tabular}{|c|c|c|c|c|c|}
\hline Sl.No & Plant Name & Locality & District & North & East \\
\hline 1 & $\begin{array}{l}\text { Leea asiatica }(\mathrm{L} .) \\
\quad \text { Ridsdale }\end{array}$ & Nilambur & Malappuram & $11^{\circ} 16^{\prime} 43.788^{\prime \prime}$ & $76^{\circ} 14^{\prime} 21.1452^{\prime \prime}$ \\
\hline 2 & $\begin{array}{l}\text { Leea asiatica }(\mathrm{L} .) \\
\text { Ridsdale }\end{array}$ & Muthappanpuzha & Kozhikode & $11^{\circ} 26^{\prime} 40.6032^{\prime \prime}$ & $76^{\circ} 5^{\prime} 14.7984^{\prime \prime}$ \\
\hline 3 & $\begin{array}{l}\text { Leea guineensis } \mathrm{G} . \\
\text { Don }\end{array}$ & Palaruvi & Kollam & $8^{\circ} 57^{\prime} 3.5136^{\prime \prime}$ & $77^{\circ} 9^{\prime} 24.4332^{\prime \prime}$ \\
\hline 4 & Leea guineensisG. Don & Pamba & Pathanamthitta & $9^{\circ} 24 ' 26.9604 "$ & $77^{\circ} 4^{\prime} 9.39^{\prime \prime}$ \\
\hline 5 & $\begin{array}{l}\text { Leea indica (Burm. f.) } \\
\text { Merr. }\end{array}$ & Venjaramoodu & Thiruvananthapuram & $8^{\circ} 40^{\prime} 57.7056^{\prime \prime}$ & $76^{\circ} 54^{\prime} 34.3476^{\prime \prime}$ \\
\hline 6 & $\begin{array}{c}\text { Leea indica (Burm. f.) } \\
\text { Merr. }\end{array}$ & Sulthan Bathery & Wayanad & $11^{\circ} 39^{\prime} 53.6256^{\prime \prime}$ & $76^{\circ} 15^{\prime} 46.6272^{\prime \prime}$ \\
\hline 7 & $\begin{array}{l}\text { Leea macrophylla } \\
\text { Roxb. ex Hornem. }\end{array}$ & Nilambur & Malappuram & $11^{\circ} 16 ' 28.0704^{\prime \prime}$ & $76^{\circ} 13^{\prime} 5.2176^{\prime \prime}$ \\
\hline 8 & $\begin{array}{l}\text { Leea macrophylla } \\
\text { Roxb. ex Hornem. }\end{array}$ & Venjaramoodu & Thiruvananthapuram & $8^{\circ} 40^{\prime} 57.7056^{\prime \prime}$ & $76^{\circ} 54^{\prime} 34.347 "$ \\
\hline 9 & $\begin{array}{l}\text { Leea rubra Blume ex } \\
\text { Spreng. }\end{array}$ & Mundakkal & Kollam & $8^{\circ} 52^{\prime} 41.0196^{\prime \prime}$ & $76^{\circ} 36^{\prime} 3.8268^{\prime \prime}$ \\
\hline 10 & $\begin{array}{l}\text { Leea rubra Blume ex } \\
\text { Spreng. }\end{array}$ & Venjaramoodu & Thiruvananthapuram & $8^{\circ} 40^{\prime} 57.7056^{\prime \prime}$ & $76^{\circ} 54^{\prime} 34.3476^{\prime \prime}$ \\
\hline
\end{tabular}

The acetolysed pollen were stored in 1:1 glycerine and distilled water and permanent slides for light microscopic studies were prepared by mounting the acetolysed pollen in glycerine jelly and sealing with paraffin wax. LM photomicrographs of the pollen preparations were taken using an Olympus CH - 20 Research Microscope with Digital camera attachment facility. The slides of pollen preparation are deposited in the Department of Botany. SEM pictures were taken at the NIIST, Pappanamcode, Trivandrum using a JEOL - JSM - 5600LV scanning electron microscope. Morphological features of pollen grains including those relating to the aperture, exine ornamentation, pollen size and shape were studied from LM and SEM observations. The value of P/E $\times 100$ was found in the case for ascertaining the shape class, following the pollen shape classification suggested by Erdtman (1966) and pollen size classes were ascertained following Walker \& Doyle (1975). The terminologies suggested by Punt et al. (1994) have been used for describing the aperture types and exine ornamentation pattern. The quantitative pollen traits (polar and equatorial pollen diameter, P/E ratio, exine thickness and aperture number were measured using an ocular micrometer, and in each case, the mean values of the measurements were taken from a random sample of 30 pollen grains. Qualitative palynological characters studied include pollen shape, type, size class, exine ornamentation, mural nature (shape, wall, width and height), luminal nature (depth, floor, shape and wax plugging) and aperture shape. 


\section{Results and Discussion;-}

Details of pollen morphological characters observed from 10 accessions representing five species of Leea D. Royen ex L., collected from different parts of Kerala State are represented in Tables 2 and 3.The pollen are in general medium-sized, 3-colporate and spheroidal with the polar and equatorial diameters ranging from $46.5 \pm 4.24 \mu \mathrm{m}$ and $46.8 \pm 3.1 \mu \mathrm{m}$ to $42.6 \pm 3.8 \mu \mathrm{m}$ and $39.9 \pm 4.5 \mu \mathrm{m}$ respectively (Table 2 ). Exine $3.15 \pm 0.71 \mu \mathrm{m}$ to $3.9 \pm 0.63 \mu \mathrm{m}$ thick, thinner towards the colpi margins and microreticulate. The aperture number was consistently 3 in all the ten taxa studied.

Table 2:- Quantitative pollen morphological characters in five speceies of Leea from Kerala

\begin{tabular}{|l|l|l|l|l|l|}
\hline \multicolumn{1}{|c|}{ Characters } & \multicolumn{1}{|c|}{ L. asiatica } & \multicolumn{1}{c|}{ L. guineensis } & \multicolumn{1}{c|}{ L. indica } & \multicolumn{1}{c|}{ L. macrophylla } & \multicolumn{1}{c|}{ L. rubra } \\
\hline Polar diameter $-\mathrm{P}(\mu \mathrm{m})$ & $45 \pm 4.9$ & $43.8 \pm 3.1$ & $46.5 \pm 4.24$ & $42.6 \pm 3.8$ & $45.6 \pm 4.73$ \\
\hline Equatorial diam.- E $(\mu \mathrm{m})$ & $40.8 \pm 3.1$ & $46.8 \pm 3.1$ & $40.5 \pm 4.24$ & $39.9 \pm 4.5$ & $41.4 \pm 7.9$ \\
\hline $\mathrm{P} / \mathrm{E}$ & $1.09 \pm 0.06$ & $0.94 \pm 0.01$ & $1.15 \pm 0.02$ & $1.07 \pm 0.05$ & $1.11 \pm 0.17$ \\
\hline Exine thickness $(\mu \mathrm{m})$ & $3.48 \pm 0.90$ & $3.21 \pm 0.7$ & $3.9 \pm 0.63$ & $3.15 \pm 0.71$ & $3.36 \pm 0.55$ \\
\hline Aperture number & 3 & 3 & 3 & 3 & 3 \\
\hline
\end{tabular}

The major qualitative palynological features were also conserved within the genus with the members having mostly prolate-spheroidal, 3-colporate, medium-sized pollen with microreticulate exine ornamentation (Table 3). The pollen in Leea guineensisand Leea indica are oblate-spheroidal and subprolate respectively. Tricolporate pollen have been observed consistently in Leea (Tarnavschi and Petria 1968; Najmaddin, 2014), while several studies have shown that they are characteristic of the closely related Vitaceae also, being mostly sub-prolate or prolate to prolate-spheroidal (Inceoglu et al., 2000; Marasali et al., 2005; Perveen and Qaiser, 2008).

Table 3:-Qualitative pollen morphological characters infive speceies of Leea from Kerala

\begin{tabular}{|l|l|l|l|l|l|}
\hline Characters & L. asiatica & L. guineensis & L. indica & L. macrophylla & L. rubra \\
\hline Pollen shape & Prolate-spheroidal & Oblate-spheroidal & Subprolate & $\begin{array}{l}\text { Prolate- } \\
\text { spheroidal }\end{array}$ & $\begin{array}{l}\text { Prolate- } \\
\text { spheroidal }\end{array}$ \\
\hline Pollen type & 3-colporate & 3-colporate & 3-colporate & 3-colporate & 3-colporate \\
\hline $\begin{array}{l}\text { Pollen size- } \\
\text { class }\end{array}$ & Medium & Medium & Medium & Medium & Medium \\
\hline $\begin{array}{l}\text { Exine } \\
\text { ornamentation }\end{array}$ & Microreticulate & Microreticulate & Microreticulate & Microreticulate & Microreticulate \\
\hline Muri shape & Heterobrochate & Heterobrochate & Heterobrochate & Heterobrochate & Heterobrochate \\
\hline $\begin{array}{l}\text { Muri wall } \\
\text { nature }\end{array}$ & $\begin{array}{l}\text { Warted } \\
\text { moderately }\end{array}$ & Warted highly & $\begin{array}{l}\text { Warted } \\
\text { moderately }\end{array}$ & Warted slightly & Warted highly \\
\hline $\begin{array}{l}\text { Muri width } \\
\text { Moderately broad }\end{array}$ & Moderately broad & $\begin{array}{l}\text { Moderately } \\
\text { broad }\end{array}$ & $\begin{array}{l}\text { Moderately } \\
\text { broad }\end{array}$ & Moderately broad \\
\hline Muri height & Tall & Tall & Tall & Tall & Tall \\
\hline Lumina depth & Deep & Deep & Deep & Deep & Deep \\
\hline $\begin{array}{l}\text { Lumina floor } \\
\text { nature }\end{array}$ & Not visible & Not visible & Not visible & Not visible & Not visible \\
\hline Lumina shape & Irregular & Irregular & Irregular & Irregular & Irregular \\
\hline $\begin{array}{l}\text { Wax plugging } \\
\text { in lumina }\end{array}$ & $\begin{array}{l}\text { Present more } \\
\text { towards the } \\
\text { mesocolpium }\end{array}$ & $\begin{array}{l}\text { Present more } \\
\text { towards the } \\
\text { mesocolpium }\end{array}$ & $\begin{array}{l}\text { Present more } \\
\text { towards the } \\
\text { mesocolpium }\end{array}$ & $\begin{array}{l}\text { Present more } \\
\text { towards the } \\
\text { mesocolpium }\end{array}$ & $\begin{array}{l}\text { Present more } \\
\text { towards the } \\
\text { mesocolpium }\end{array}$ \\
\hline $\begin{array}{l}\text { Aperture } \\
\text { shape }\end{array}$ & Colporate & Colporate & Colporate & Colporate & Colporate \\
\hline Colpi margin & Slightly winged & Slightly winged & Slightly winged & Slightly winged & Slightly winged \\
\hline
\end{tabular}

The lumina were heterobrochate and irregular in shape, bounded by tall, moderately broad muri with small granular warts on their upper surfaces. The mural surfaces were heavily warted in Leea guineensis and Leea rubra, while those of Leea macrophylla showed the least incidence of warts. The narrow lumina limited by tall muri appeared 
deep, making the pollen microreticulate rather than reticulate. The very deep luminal floors were not clearly visible due to the height of the mural walls. The lumina appeared to be variously shaped assuming irregularly oval, ellipsoidal or round appearances. In all cases the lumina appeared to be very often plugged with waxy deposits, more frequently at the mesocolpium. Roytchev et al. (1994) noted that the colpiare usually wide and deep in the equatorial zone, narrowing towards the poles. In addition, the present study revealed that the colpi margins are slightly winged in Leea.

Both Leeaceae and its close kin the Vitaceae have been reported to be stenopalynous, being characterised by tricolporate, reticulate pollen. Perveen and Qaiser (2008) grouped the pollen of Vitaceae into three types based on exine ornamentation, among which the Ampelopsis vitifolia subsp. hazaraganjiensis-type alone had reticulate exine. Although the Leeaceae pollen have been repeatedly reported as reticulate, the narrow deep lumina bounded by tall muri give them a porous appearance and consequently the exine ornamentation may be more aptly considered to be microreticulate. The reticulum is more clear towards the apocolpia, while the lumina tend to elongate and narrow at the mesocolpium assuming a rugulate nature. This was observed in all the five species and appears to be more effected by the waxy embedding at the mesocolpium. Reduction in luminal width towards the equatorial region was observed earlier by Faegri and Iversen (1989) in the closely related genus Vitis, and this was later recorded as foveolate-rugulate or rugulate-striate exine ornamentation at the mesocolpium (Inceoglu et al. 2000; Najmaddin et al 2011) based on the SEM studies on the pollen of Vitisspecies. However, the authors have not come across such observations on the pollen of Leea.

The systematic hierarchy of Leea in relation to its closely related family the Vitaceae has been flooded with much controversy, with taxonomists either separating it out as a distinct family - the Leeaceae owing to its unique erect shrubby habit, absence of tendrils, terminal inflorescences, large stipules, complex floral disc, staminoidal tube, secondary septa in ovary, variations in ovule and carpel number etc. (Dumortier, 1829; Risdale, 1974, 1976; Wen, 2007; Molina, 2009), or including the genus as a separate subfamily Leeoideae along with the larger subfamily Vitioideae under the Vitaceae ( APG I998 to APG IV, 2016), due to the common possession of pearl glands, barbed raphides, phloem-plastids, antipetalous stamen, ruminate seeds with oily endosperm etc. and similar floral development. The present study unveiled much similarity between the pollen morphological traits of the two subfamilies of the Vitaceae, the details of which have already been discussed in the paragraphs above. The stenopalynous nature of the two subfamilies along with the conservation of the major pollen characters in them support the inclusion of the genus Leea as a subfamily (Leeoideae) under the family Vitaceae.

\section{Conclusions:-}

The monotypic genus Leea of the stenopalynous family Leeaceae is characterized by mostly prolate-spheroidal to subprolate, 3-colporate, medium-sized pollen with microreticulateexine ornamentation. The colpi demarcated by slightly winged margins, are wider and deeper towards the equatorial zone. The tall muri with warted upper surfaces enclose deep irregularly heterobrochate narrow lumina, very often plugged with waxy deposits, more frequently at the mesocolpium. The reticulum is more clear towards the apocolpia, while the lumina tend to elongate and narrow at the mesocolpium assuming a rugulate nature. These major pollen traits appear to be heavily conserved not only within the genus, but also within the closely related family Vitaceae as well, justifying the inclusion of the genus as a separate subfamily Leeoideae along with the larger subfamily Vitioideae under the Vitaceae. 

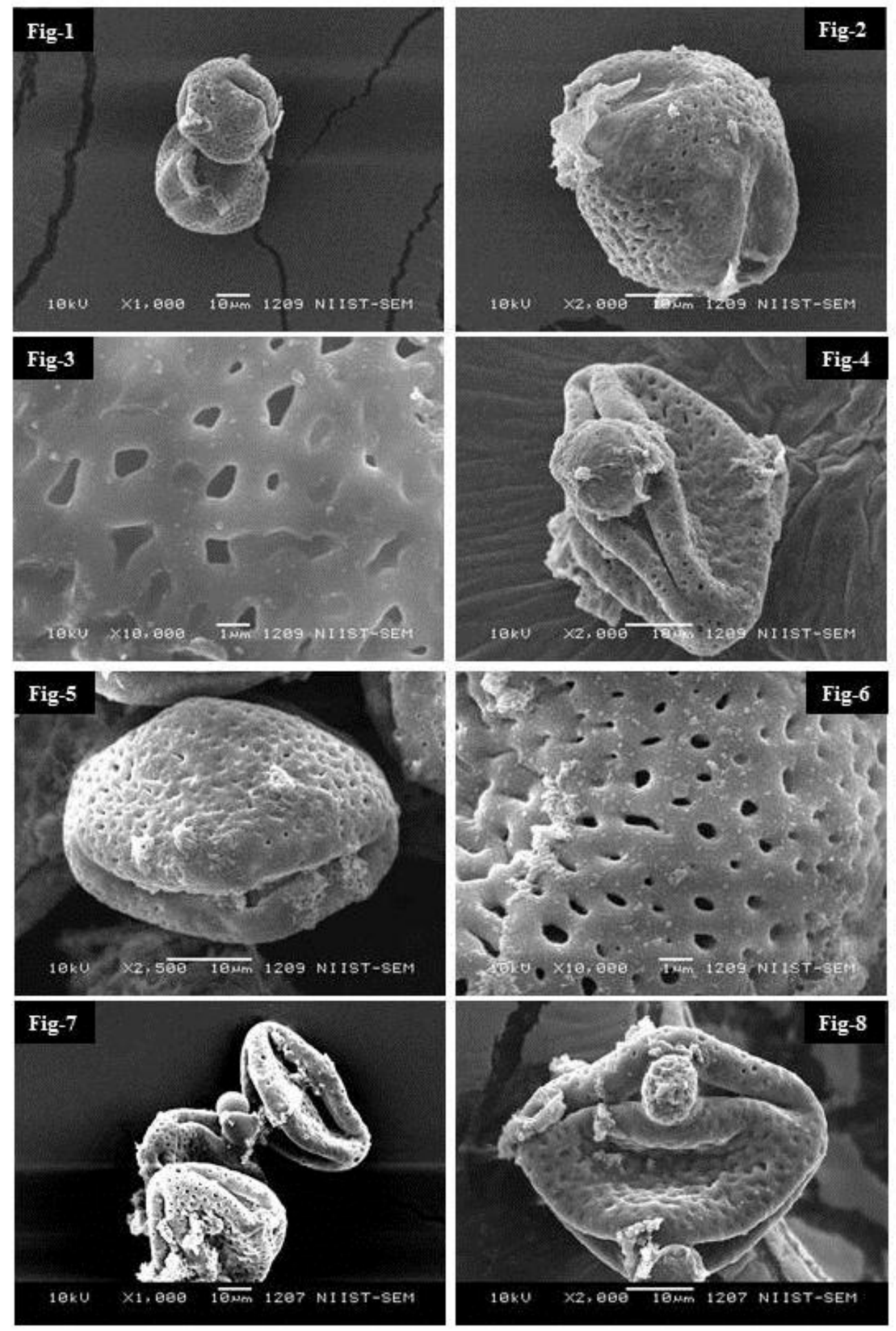

Figs. 1-3:-Leea asiatica (L.) Ridsdale, pollen- 1000x, 2000x, 10000x; Figs. 4-6: Leea guineensis G. Don, pollen2000x, 2500x, 10000x; Figs. 7-8: Leea indica (Burm. f.) Merr., pollen- 1000x, 2000x 

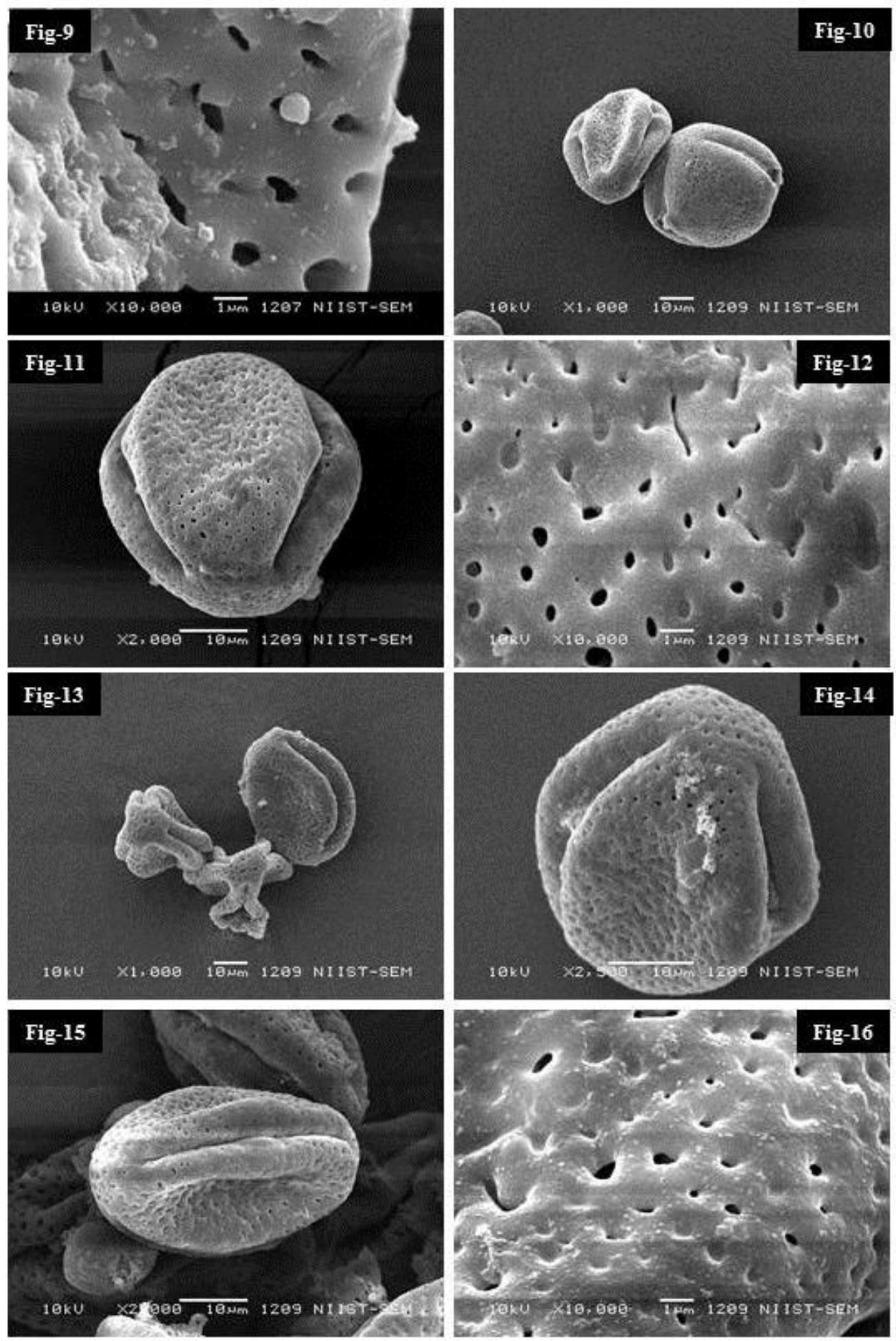

Fig. 9:-Leea indica (Burm. f.) Merr., pollen- 10000x; Figs. 10-12: Leea macrophylla Roxb. ex Hornem., pollen1000x, 2000x, 10000x; Figs. 13-16: Leea rubra Blume ex Spreng., pollen- 1000x, 2500x, 2000x, 10000x 


\section{Acknowledgements:-}

The authors are thankful to the University of Kerala for financial support, ERRC, Thiruvananthapuram and the Principal, SreeNarayana College, Kollam for facilities provided.

\section{References:-}

1. APG I (1998): Stevens, P. F. Angiosperm Phylogeny Website. http://www.mobot.org/MOBOT/research/APweb/.

2. APG II (2003): Stevens, P. F. Angiosperm Phylogeny Website. http://www.mobot.org/MOBOT/research/APweb/.

3. APG III (2009): Stevens, P. F. Angiosperm Phylogeny Website. Version 9, June 2008.

4. APGIV (2016). "An update of the Angiosperm Phylogeny Group classification for the orders and families of flowering plants. http://en.wikipedia. org/wiki/APG_IV_system.

5. Najmaddin, C., Hussin, K. and Maideen, H.(2011):African Journal of Biotechnology, Vol. 10(74), pp. 1686616874., 1SSN 1684-5315.

6. Najmaddin, C. (2014): Anatomical and Palynological studies of Cissus quadrangularis and Cayratia geniculata (Vitaceae) and Leea angulata (Leeaceae). Journal of University of Duhok, Vol. 17, No.1(Pure and Eng. Sciences), Pp 108 - 118.

7. Dumortier, B. C. (1829): Analyse des families des plantes, 27.

8. Erdtman, G. (1952):Pollen Morphology and Plant Taxonomy of Angiosperms. Almquist and Wiksell, Stockholm.

9. Erdtman, G. (1966):Pollen Morphology and Plant Taxonomy of Angiosperms. Corrected reprint of the edition of 1952 with a new addendum. Hafner Pub. No:NV.

10. Faegri, K. and Iversen, J. (1989): Textbook of Pollen Analysis. - J.Wiley, Chichester.

11. Inceogul, O., Pinar, N.M. and Oybank-Donmez, E. (2000): Pollen Morphology of wild Vitis sylvestrisGmelin (Vitaceae). Tur.Jou. of Bot., 24: 147-150.

12. Marasali, B., Pinar, M. and Buyukkartal, N. (2005): Palynological study on the pollen grains of selected Turkish grape (Vitis vinifera L.) cultivars.Tur. Jou. of Agri. and For., 29:75-81.

13. Molina, J. (2009): Floral biology of Philippine morphospecies of the grape relative Leea. Plant Species Biology, 24: 53-60.

14. Moore, P.D., Webb, J.A. and Collinson, M.E. (1991): Pollen analysis. Blackwell Scientific Publication.

15. Nair,P.K.K. (1970):Pollen Morphology of Angiosperms. III. Historical and Phylogenetic Study.Vikas Pub. House, Delhi.

16. Perveen, A. and Qaiser, M. (2008): Pollen flora of Pakisthan-LVII. Vitaceae. Pak.Jou.of Bot., 40 (2): 501-506.

17. Punt, W., Blackmore, S., Nilsson, S.and Le Thomas, A. (1994):Glossary of Pollen and Spore Terminology. LPP Contributions Series No.1. LPP Foundation, Uty. Of Utrecht, The Netherlands.

18. Punt., W., Marks, A. andHoen, P.P. (2003): Vitaceae, The Northwest European Pollen Flora64, Review of Palaeobotany and Palynology 123. 67-70.

19. Ridsdale, C. E.(1976): Leeaceae. Flora Malesiana, Series 1, 7: 775-782.

20. Ridsdale, C.E. (1974): A revision of the family Leeaceae.Blumea, 22(1): 57-100.

21. Ridsdale, C.E. (1975): Leeaceae. In: van Steenis, C.G.G.J. (Ed.). Flora Malesiana .Series 1, Vol. 7(4).Noordhoff, Leyden, the Netherlands. pp. 755-782.

22. Roytchev, V., Terziisky, D., Dimova, D. and Karageorgiev, S. (1994): Scanning electron microscopy study of pollen morphology in seedless grape (Vitis viniferaL.) cultivars. Vitis, 33: 105-108.

23. Sasidharan, N. (2004):Flowering Plants of Kerala.Biodiversity Documentation for Kerala, Part 6.

24. Tarnavschi, I. T. andPetria, E.(1968): Contribution to the knowledge of the microsporial structures in the family Leeaceae. Pollen et Spores, 10: 221-249.

25. Tewari, R.B.and Nair, P.K.K. (1978): Apertural forms and their evolutionary trends in the pollen grains of Indian Papilionaceae. Ind. J. Bot.,1(1 \& 2): 133-138.

26. Walker, J.W. and Doyle, J.A. (1975): The basis of angiosperm phylogeny: Palynology. Ann. Miss. Bot. Gard., 62:664-723.

27. Wen, J. (2007): Leeaceae. In :Kubitzki K.(ed.). The families and Genera of Vascular Plants, Vol.9. SpingerVerlag, Berlin, pp.221-225. 